\title{
British Taxation in Nigeria: The Ekwunekwune Resistance of 1954
}

\author{
Francis C. Odeke* \\ Department of History and International Relations, Faculty of Social Sciences and Humanities, Ebonyi State \\ University, Abakaliki
}

*Corresponding Author: Francis C. Odeke, Department of History and International Relations, Faculty of Social Sciences and Humanities, Ebonyi State University, Abakaliki

\begin{abstract}
It was the British imperialists who could not pronounce it properly that adulterated the name to "Akunakuna". The real name of the people is Ekwunekwune which means "a land of bird nests" because of the abundance of birds, bird nests and bird eggs that were found in the thick forest when they drove away some Cross Riverian communities from the area. In 1954 the people of Ekwunekwune revolted against the British direct taxation and Education Rate which were introduced in Nigeria on April I, 1928 and the Abakaliki Division in 1953, respectively. This paper examines the remote causes, organization and consequences of that revolt. The paper adopted the analytic and narrative approach of history, using the primary and secondary sources to assess its data. The paper establishes that the Ekwunekwune revolt was actually spurred by the women of the community who tried to save their husbands from over taxation and improper imprisonment. The paper argues in conclusion that the manner of introduction and enforcement of the taxes and the inclusion of women in the tax system, all contributed to the weakening of the British colonial government in Nigeria.
\end{abstract}

Keywords: Ekwunekwune, Imperialism, Colonialism, Taxation, Education Rating, Imprisonment, Resistance

\section{INTRODUCTION}

\subsection{Geographical Location of Ekwunekwune}

Ekwunekwune is a rural village in Amagu Ikwo autonomous community in Ikwo Local Government Area of Ebonyi State, Nigeria. The village lies between $6^{0} 41^{\mathrm{I}} 30^{\mathrm{II}} \mathrm{N}$, and $3^{0} 18^{\mathrm{I}} 0^{\mathrm{II}} \mathrm{E}$. It is bounded on the north by Agalegu village; on the South by Ndeagu village; on the East by Igbudu and Inyimagu villages; and on the West by Abina and Nde Ofeke Villages.

Ekwunekwune is part of the forest zone of Nigeria. It shares in the wetter climate of the south-eastern part of the country. A dense vegetation area, the village has a longer rainy season that encourages the growth of perennial tree crop like the oil palm.1 Possibly, due to continuous and extensive farming activities, Ekwunekwune could be qualified as a derived savanna vegetation belt area where natural forests have all disappeared and replaced by oil palm bushes. The longer rainy season of the region equally encourages the planting of root crops such as yams, cassava and cocoyams. 2

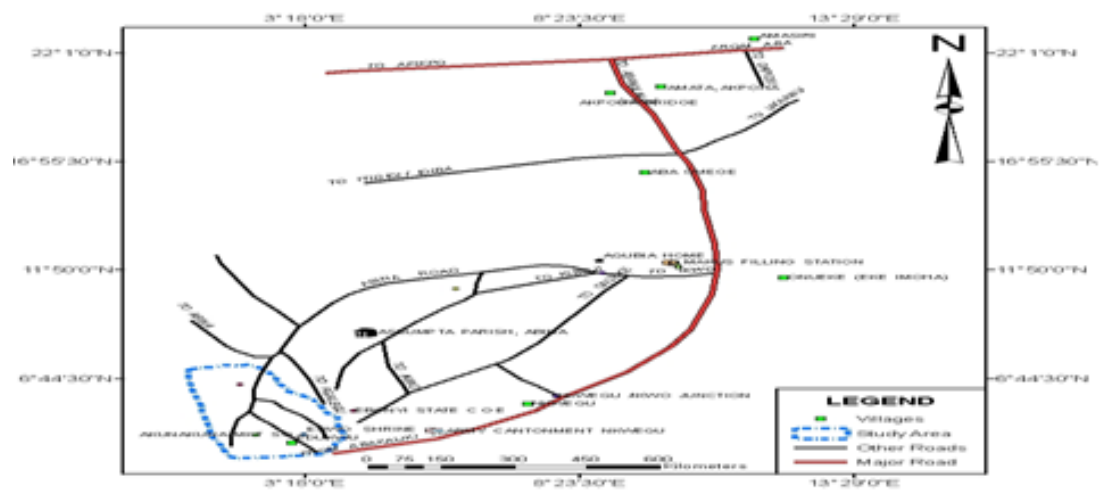

Fig1. A Road Map of Ekwunekwune

Source: Researcher's Fieldwork Computation 
It was the British colonial missionaries who sailed across the Cross River into Ekwunekwune from Calabar in 1949, that adulterated the name of the village to "Akunakuna", a derogatory title of a prostitute in Igbo-name system. The wrong name has stuck till date. John O. Nwakpuru a retired Headmaster and an indigene of Ekwunekwune, said that his community was a thick forest with abundant egg laying birds in nests which the women easily picked into baskets and carried home as part of their family meals. He maintained that his ancestors named the forest "Ekwunekwune" because they were amazed by the abundance of birds and bird nests they saw in the forest ${ }^{3}$. Some Cross Riverian communities were living in the forest but were driven away by the ancestors of the present inhabitants through an extensive war for farm lands.

\subsection{Who are the Ekwunekwune People?}

Ekwunekwune is part of the Ikwo clan, a sub-clan of the three main clans of the Abakaliki people in the North-East of Igbo land. The origin of the Abakaliki people is still shrouded in controversy. Nonetheless, historians suppose the people to be descendants of Anakewhaliki who was the father of Ekuma Enyi and Ezeke Una. Anakewhaliki was said to have contracted the small-pox disease, known in local dialect as Igbogbo, a dreaded disease then regarded as a bad curse on whoever contracted it. Anakewhaliki later died of the disease and was denied a befitting burial but was thrown into Ebonyi furu-egu, an evil forest located till date at Amana, the ancestral home of the Ezza people ${ }^{4}$.

Ekuma Enyi later married and had two sons-Nnodo and Noyo, while Ezeke Una (now shortened to Ezekuna) also got married but had four sons, with Oroke Onuoha as the first. Nnodo begat sons that established the Izzi Clan; Noyo also begat sons that established the Ikwo clan; while Oroke Onuoha and other sons of Ezekuna founded the Ezza clan. It was the later sons of Noyo, namely Alike, Ekpa, Mgboabor, Echara, and Ekpa Omaka, that expanded as Ikwo Clan ${ }^{5}$. Each of these sons of Noyo later begat his own sons to further extend the spread of the family. Oral accounts had it that Mgboabor had a son called Erim Ogwudu with whom he was paired in the family's elaborate plans for expansion.

Mgboabor and Erim Ogwudu, his son, were assigned the defense of the southern part of the Ikwo clan. Their first war was with the Ekwurekwu people, a Cross Riverian community, whom they drove away and pitched their first home in the south at Ohatekwe. It was from there that they fought their second war with the Otum group, another Cross Riverian community that was driven out from their settlement which was renamed Egu-nwenu, and later Nde Ofeke, after the name of Mgboabor's major deity. By the time age could not let Mgboabor continue with the leadership of the group, Erim Ogwudu who had begotten two sons-Omara and Amogu6, took over the mantle and kept a steady expansion of the family by creating more villages like Agalegu-Amagu.

It was from Agalegu-Amagu that Erim Ogwudu crossed a small creek with his men to drive away another Cross Riverian group known as the Ekpete, from a lush forest on the eastern flank of Agalegu. It was the astonishing abundance of birds and bird-eggs in nests in the forest that prompted Erim Ogwudu to name the forest Ekwunekwune. But in 1949, the British colonial missionaries adulterated the name to "Akunakuna".

\subsection{How the British Penetrated Ekwunekwune}

The last major war of the British with the Abakaliki people was in 1907 when Ngboejeogu clan was finally subdued under British colonial rule ${ }^{7}$. From then till the early 1940s, Ekwunekwune remained its obscure self without any interference from any foreign power that was eager for the resources of the hinterland communities. But in mid 1940s, that privilege was broken when some British missionaries of the Catholic Church from Calabar, sailed into Igbudu, a neighbouring village to Ekwunekwune on the east, where they mustered a handful of adherents for the Christianization of Ekwunekwune. On getting to Ekwunekwune, the missionaries and their guides from Igbudu were forcefully resisted by the people. Many of the missionaries and some of their guides from were said to have been killed. Thus frustrated, the missionaries went back to Calabar ${ }^{8}$.

In 1949, the Christian Missionaries Society, CMS, a group from Scotland, which later founded the Presbyterian Church of Nigeria, penetrated Ekwunekwune with some Igbo converts from Onitsha, Awka, Afikpo and Ohafia, who led the missionaries by bicycles into the village. The missionaries camped at Mgboabor, an Ekwunekwune sub-village. But the people's hostility was still high, and with mosquito attacks, the stay of the missionaries at Mgboabor was brief. They moved to Abina, another neighbouring village of Ekwunekwune on the west, from where they frequently visited Ekwunekwune 
to preach the gospel of Christianity. An indigenous source said that the missionaries were "coming to do business and to spread the religion of Christianity"9 in the village. It was the presence of the missionaries that attracted a government primary school named Mgboabor Community Primary School, to Ekwunekwune in about 1950. With the school, the colonial government began other efforts to take over effective direct control of the people and their affairs ${ }^{10}$.

To many in Ekwunekwune, British colonialism was led into the village by Christianity. John Nwakpuru said his people had lived in recluse for many years before their peace was shattered by the missionaries who, though resisted initially, refused to leave the community alone. Their insistence turned life in the village upside down, causing many to renounce the ways of their ancestors while foreign cultures that were too strange to the people, were forced on them. Dominic Aloh observed that nobody in Ekwunekwune noticed the long plan of the British government to take over the land of the people and rule it perpetually to British interests. ${ }^{12}$ Nwakpuru maintained that the British tax war against his community was intensified by the fact that the colonizers could not find any other means of sustaining the newly introduced colonial administration. ${ }^{13}$ Cornelius Alobu, first indigenous Councilor in Ekwunekwune, saw some justifications in colonial rule but said that the resistance of his people to the British tax policies was due to the failure of the colonial government to allow the people a participation in the decision process that resulted to direct taxation. ${ }^{14}$

Before the introduction of taxation, the people of Ekwunekwune were unknown and never consulted in the decision that led to the imposition of taxes. To a people that had lived by and enjoyed democracy where decisions on matters of common interest were openly taken in the village square with all male adults in attendance, imposing a decision taken by unknown people, especially when it involved parting with one's hard earned money, was bound to precipitate resistance. ${ }^{15}$

\section{BRitish Taxation in Nigeria AND the PeOple's Resistance}

It was Federick Lugard, first British High Commissioner of the Northern protectorate of Nigeria who brought the idea of taxation in the country. He began experimenting the idea with the Native Revenue Ordinance which was based on existing Islamic laws in the region. With the amalgamation of the Northern and Southern protectorates in 1914, Lugard extended the Native Revenue Ordinance to the western province (which was still part of the southern protectorate then) between 1917 and 1920 because the area had a centralized leadership and the chiefs were said to have voluntarily accepted the imposition of indirect rule on their subjects ${ }^{16}$. Lugard was anxious within the same period to extend the Ordinance to the south-eastern part of the new country as a way of letting the people know that they had both economic and civic responsibilities to the State. He was advised against the move because of its potential grave implications. Nonetheless, Lugard devised other means to collect revenue from the people in order to sustain his colonial administration.

He ordered that the excess funds of the Native Courts in the region which had been managed as District Funds for local developments, should be paid into the General Revenue until such a time tax revenues could be derived from the people ${ }^{17}$. The South was financially viable due to the custom duties from the export/import trade in the region. That partly made the introduction of direct taxation in the area unattractive. Initial disapproval to Lugard's order came from other colonial administrators like Hugh Clifford who argued that any attempt to create a centralized leadership in the south-east as obtained in the Hausa and Yoruba states "is to build an edifice upon a quick sand" 18 . Indirect taxes had existed in the south-east before Lugard's innovation. Thousands of men had been forced to work without pay on a variety of public works such as building and maintenance of roads, construction of railways and government stations on government fixed wages. The young men were often conscripted by their local chiefs who soon fell out of favour with their subjects for being instrumental to their conscription. ${ }^{19}$

To Lugard, the forced labour of the Southern Province, together with the custom duties from their import/export trade, were not enough to guarantee the long term financial needs of the state. Increasing fiscal budgets of the government, resistance to forced labour, the criticism of the British liberal and leftist groups, and the investigation by the permanent mandate commission of the League of Nations forced the colonial government, through the Legislative Council, to consider in 1927, the idea of extending the Native Revenue Ordinance as operative in the Northern Provinces, to the Eastern Provinces as from April 1, $1928^{20}$. The Native Revenue Ordinance was partially successful in 
the Western Provinces, and absolutely successful in the Northern Provinces because of their centralized system of leadership ${ }^{21}$. The Yoruba of the Western Provinces were used to paying tributes to the Oba or Alafin. In the North, Othman dan Fodio had conquered the Hausa states in 1804, and introduced various forms of taxes and tributes under Islamic laws ${ }^{22}$. Thus, it was easy for the British to fit in the Native Revenue Ordinance into these two Provinces based on existing native laws.

In the south-eastern Provinces where centralization of authority was unknown, the Native Revenue Ordinance which ushered in direct taxation was met with resistance. The people were reluctant to pay taxes whose end benefits were not explained to them. They were used to levying themselves for specific community projects. The British colonial government merely imposed taxes and appointed Warrant Chiefs as tax agents without educating the people on the benefits of the taxes. The result of that oversight was a spate of resistance beginning from 1927 when the idea of taxation was mooted, through 1938/1939 when tax protests became wide spread throughout the entire Provinces of southeast. The most epochal was the Aba Women Riot of 1929 of which Philip Effiong wrote that

thousands of southeastern women........ organized a massive revolt against taxation policies imposed on market women. The rebellion was a prime instance of feminist and anti-colonial crusades.....Gathering in large numbers at various administrative offices, the women questioned the new tax laws and confronted power-crazed 'warrant chiefs' that had been appointed to serve as local agents of the British through the system of indirect rule ${ }^{23}$.

\section{The EKWUnekwUne Tax Resistance OF 1954}

Not much was known of the Abakaliki people and their reactions to British introduction of direct taxation in 1928. What actually popularized the British presence in the area was the forcing of thousands of young men to build residences and administrative quarters for the colonizers in Abakaliki town. Then, the creation of Native Courts into which some indigenes were appointed as members and later elevated as warrant chiefs for purposes of collecting taxes, exposed the British colonial rule as an exploitative system. The chiefs soon became corrupt and high-handed to the disappointment of their people. But the British colonizers did not care because they needed such hardened men to serve their interests. The corrupt indulgencies of the chiefs resulted to chains of protests in all communities of Abakaliki. The republican and democratic nature of the people could not tolerate certain obnoxious practices. ${ }^{24}$

The introduction of the education rate in 1953 heightened the anger of the people who felt disregarded by the British whom they accused of introducing all their taxes before attempting to explain their advantages. Men who could not afford the taxes were hounded into prisons while many abandoned their homes into the farms and forests to escape arrest. Families were disintegrated in the confusion, and wives and children suffered untold hardship. The result was the Division- wide outburst of the women in $1954^{25}$. Led by Usulor Enyi Mbgaji and other patriotic women in the Abakaliki Division, the women rounded up some chiefs and other tax agents and brought them to Eke Imoha where they were beaten and humiliated. ${ }^{26}$ The Ekwunekwune disturbance was an extension of the Abakaliki women Riot.

The spirited fight of the women against the British colonial government spurred the men of Ekwunekwune to stand firmly in resistance to the education rate which was seen as unnecessary because the people had no interest in Western education. Again, they saw the rate as an expansion of the authority of the Native Authority government, a creation of the colonial government, to increase their corrupt and exploitative tendencies. The attempts by the Native Authority Government to educate the people on the benefits of the education rate aggravated the anger of the people, resulting to the issuance of warrants to court messengers and the police to arrest those who were obstructing payment of the Rate. But the officers could not effect any arrest in the face of fierce resistance.

The failure informed the visit of the Senior District Officer, accompanied by the Councilors from Ikwo and some police officers, to Ekwunekwune on February 25, 1954, to persuade the men to comply with the education rate policy. The visit was unsuccessful as the government officials were snubbed, and later ambushed and attacked on their way back to Abakaliki. The two councilors from Ikwo and some other government officials were snubbed, and later ambushed and attacked on their way back to Abakaliki. The two Councillors from Ikwo together with other government staff, were abducted. The next day, the Senior District Officer, his assistant, some Senior Police Officers of 
Abakaliki Division, with two riot police units from Enugu, went back to Ekwunekwune to secure the release of the abducted men $^{27}$. The venue of the meeting was the Edukwu play ground in Ekwunekwune where the elders (Nde Ichie) were said to have seated in the front row while cutlasscarrying young men lined battle ready behind them.

Addressing the people, the Senior District Officer insisted that the abducted Councilors and others, should be released to him before the government team could leave Ekwunekwune. To the men of the land, the Senior District Officer had threatened the entire community by his insistence ${ }^{27}$. What followed was dramatic. The elders (Nde Ichie) quickly moved to the rear of the crowd while the young men with their cutlasses, surged forward circling the government team. The police officers tried to force back the armed young men with battons and carnisters without success as many of the carnisters were picked and thrown back at the police. In the confusion, a Senior Superintendent of police fired a revolver shot which killed a young man instantly, causing others to go berserk on the visitors.

As more revolver shots were fired at the rampaging crowd, two other indigenous young men were killed while the third who was seriously injured, died shortly after. In all, about twenty-eight indigenes were arrested and tried before a British magistrate sitting in Abakaliki ${ }^{28}$. In a nostalgic explanation of the incident, an indigene of Ekwunekwune said that many of the visitors were killed by his people while several others were wounded ${ }^{29}$. But the report of the Chief Secretary to the Council of Ministers was silent on that claim though it noted that

the whole affair seems to have been conducted with a regrettable degree of savagery. Both the police officers and other ranks who took part in the action have expressed the view that they have never in this country experienced such a determined and well organized attack. ${ }^{30}$

\section{RESUlts OF THE RESISTANCE AND CONCLUSION}

The Ekwunekwune disturbance of $25 / 26^{\text {th }}$ February, 1954, was actually an extension of the Divisionwide Abakaliki Women Riot against what was generally called "over taxation and unnecessary education rate". Ekwunekwune women had participated massively in the protest by which many warrant chiefs and other agents of the colonial government were publicly humiliated at Eke Imoha. The unprecedented will of the women spurred the men in Ekwunekwue into their solemn resolve against British tax policies. The result was their bloody confrontation with the colonial government in the Abakaliki Division with its concomitant casualties on both the indigenes and government. An unbelievable outcome of the confrontation was its prevention of further attempts to persuade the people of Ekwunekwune to pay either the direct tax, education rate or any other tax. That, to the indigenes, was a major victory against the British colonial government in Nigeria ${ }^{31}$.

On the other hand, it was the British disregard to the people's peculiar socio-cultural and political background that encouraged the wide spread rebellion against British tax policies in Nigeria, and finally contributed to the weakening of the entire colonial system in the country, most especially in the Eastern Provinces.

\section{REFERENCES}

[1] Reuben K.Udo, "Environments and Peoples of Nigeria: A Geographical Introduction to the History of Nigeria" in Groundwork of Nigerian History (Obaro Ikime ed.), Ibadan: Heinemann, 1980.p.11

[2] Reuban K. Udo, p.11

[3] John O. Nwakpuru, c.83; a retired Headmaster and an indigene of Ekwunekwune, spoke with me on the 4/9/2010.

[4] Philip A. Nwinya, "Ezza Wars of Expansion And The British Intervention, 1805", an M.A. Thesis Proposal submitted to the Department of History and International Relations, Ebonyi State University, Abakaliki. 2016. p.12.

[5] See Nico van Steensel, The Izhi: Their History and Customs, Abakaliki: Abakaliki Literacy and Translation Committee, 2009, p.6; and Njoku Afoke and Micheal P. Nworie, Ezza History, Culture and Civilization, Enugu: CIDJAP Press, 2010. p.8.

[6] John O. Nwakpuru, 4/09/2010.

[7] Igiri Daniel Omogo, Ngboejeogu and The People, Unwuogudu Osha Ngbo: Amos Onwe, 2012.p. 224

[8] John O. Nwakpuru, 4/09/2010 
[9] Dominic Aloh, c.75; Erim Ogwudu III; Paramount Head of Amagu Ikwo Autonomous Community, spoke with me on 14/09/2010, in his Palace at Agalegu-Amagu, Ikwo Local Government Area, Ebonyi State, Nigeria.

[10] John O. Nwakpuru, 4/09/2010.

[11] John O. Nwakpuru, 4/09/2010

[12] Dominic Aloh, 14/09/2010.

[13] John O. Nwakpuru, 4/09/2010.

[14] Cornelius Alobu, c.48; first indigenous Councillor of Ekwunekwune, spoke with me in his compound at Ekwuenekwune village on 4/09/2010. Cornelius lamented the total neglect of his community by all postcolonial governments of Nigeria till his election as a Councilor.

[15] Cornelius Alobu, 4/09/2010.

[16] Ben Naanen, "You are Demanding Tax From The Dead: The Introduction of Direct taxation and its Aftermath in South-Eastern Nigeria, 1928-1939”, African Economic History, vol. 34. 2006:69-102.

[17] Ben Naanen

[18] S. O. Okafor, Indirect Rule: The Development of Central Legislature In Nigeria, Lagos: Thomas Nelson and Sons Ltd; 1981.p.84.

[19] Report of the commission of inquiry into the disturbances in the Calabar and Owerri Provinces, vol.1. section 8: 7, 1930. This report was the result of the government investigation of the Women's Riot of 1929.

[20] The financial state of Northern Protectorate was partly responsible for the amalgamation of that Protectorate with the Southern Protectorate in 1914. The amalgamation provided financial rationalization that was of great relief to the Northern Protectorate.

[21] Ben Naanen, "You Are Demanding Tax From the Dead..."

[22] Micheal Crowder, The Story of Nigeria, London: Faber and Faber, 1981.p.83.

[23] Philip Effiong, “1929 and 1946: Nigerian Women Resist Colonial Laws”. Online, 20/04/2018.

[24] Uche U. Okonkwo and Ndubuisi M. Mbam, He Was Not Given Fair Hearing: Chief Nwiboko Obodo of Colonial Abakaliki, 1893-1959, Enugu: Madonna University Press, 2016.p.1

[25] "Education Rating in Abakaliki (19481954)". AIDIST 5/1/64. National Archives, Enugu.

[26] “Disturbances in Abakaliki (1953-1954).” AIDIST 5/1/87. National Archives, Enugu.

[27] "Disturbances At Akunakuna", A report of the Chief Secretary to the Council of Ministers, dated March 12, 1954. CO: 1039/24: 283810.

[28] "Disturbances At Akunakuna"....

[29] Dominic Aloh, 14/04/2010.

[30] "Disturbances At Akunakuna...."

[31] John O. Nwakpuru, 04/09/2010

Citation: Francis C. Odeke, “British Taxation in Nigeria: The Ekwunekwune Resistance of 1954”, 19822012: An Historical Appraisal, 1846 -2015. International Journal of History and Cultural Studies (IJHCS). vol 4, no. 3, 2018, pp. 8-13. doi: DOI: http://dx.doi.org/ 10.20431/2454-7654.0403002.

Copyright: (C) 2018 Authors. This is an open-access article distributed under the terms of the Creative Commons Attribution License, which permits unrestricted use, distribution, and reproduction in any medium, provided the original author and source are credited. 